\title{
FUTURE FROM THE PAST
}

\author{
Andrey V. Yurevich \\ Institute of Psychology, Russian Academy of Sciences \\ Moscow
}

\begin{abstract}
The author demonstrates that the bulk of futurological forecasts do not come true as well as predictions contained in scientific fiction. In his view the systematic mistakes of such forecasts are due not to the shortcomings of predictions, but to the fact that the development of civilization is unfolding in irrational direction. It is connected with the substitution of "paradigm of development" by the "paradigm of entertainment" - the distinguishingly manifested process which has psychological roots. The author states that underestimation of the changes in human psychology is still alive and well in futurological forecasts what diminishes their exactness.
\end{abstract}

Keywords: futurology, scientific fiction, forecasts, systematic mistake, civilization, psychology, science, technology, "paradigm of development," "paradigm of entertainment."

\section{The mistakes of futurology}

Humankind has forever sought to extend its time perspective by linking its interest in the present with the lessons of the past and attempting to look into the future. F.L. Polak stressed that throughout history the development of civilization has been stimulated and guided by the images of the future created by the more gifted and talented members of society (Polak, 1973, p. 7). One of the best known researchers of science, E. Torrance, analyzed historical episodes to demonstrate, first, that science and culture have always been spurred by vivid images of the future which exerted massive influence on them, and second, that the potential "strength" of this or that culture was proportional to the clarity and vigor of these images (Torrance, 1978). "Future shocks" eloquently described by A. Toffler (Toffler, 1970) often provided irritants for mankind whose impact was every bit as strong as the challenges of the present.

Predicting the future, once the traditional occupation of palm-readers and star-gazers, has turned into a major industry which has scientific 
and cultural elements (at present, though, the burgeoning popularity of star-gazers and palm-readers has prompted a movement in the opposite direction). The role of the former has been taken on by futurology and of the latter, by science fiction as well as the plots it has suggested to the media, the cinema, etc. In the 1970s studies of the future were already a rapidly developing multi-million dollar industry (Dickson, 1977, p. 4). In the US, for example, there were more than 400 independent futurological groups that used more than 150 various prognostication methodologies (Ibid.). By the 1970s science fiction had emerged as one of the most popular literary genres.

Many of the science fiction and futurological forecasts were set in 2000 because of the magic spell of the date separating millennia. As J. Benford noted, everybody wanted to peep behind the veil that hid the magic number 2000 (Benford, 1995, p. 1). Now that we are into the $21^{\text {st }}$ century there is every opportunity to look at the future-turned-present through the prism of the past, i.e. see to what extent predictions have come true.

Let us cite some forecasts made by leading futurologists in the 1970s.

- There will be transplanting of all the main human organs, with the exception of the brain, from donors, as well as the grafting of artificial organs which would make it possible to constantly rejuvenate the human organism (Toffler, 1976).

- We will be able to rear children with super-normal sensory and physical abilities (Ibid.).

- The governments of totalitarian countries, riding roughshod over public opinion, will make wide use of genetic engineering to grow geniuses and highly gifted individuals who, of course, will be used to pursue totalitarian goals, and democratic countries will have no option but to respond. The result would be an artificially bred "genetic race" (Ibid.).

- A "psycho-neurological revolution" would make the brain absolutely "transparent," we will learn to generate in ourselves various mental states through electrical stimulation of certain areas of the brain, will become adept at extrasensory perception and telepathy and will practice "brainwashing" on a massive scale, etc. (RitchieCalder, 1976).

- Microorganisms will be one of the main sources of protein food (Asimov, 1976). 
- We will be able to choose the sex of our children (Wheeler, 1976).

- The blind will be provided with "artificial eyesight" with the help of electronic sensors (Dickson, 1977).

- Cars will be driven by computers, there will be no need for drivers (Ibid.).

- Much of the energy consumed by humanity will come from interplanetary solar stations (Ibid.).

- There will be submarine hotels and health resorts (Ibid.).

- Man will control the weather, including hurricanes (Ibid.).

Doing justice to these bold futurological forecasts one must say that science fiction writers were even bolder. In the Space Odysseys of 2001 and the following years people visit the remotest corners of the Universe, marry extraterrestrials, use Mars and Venus to provide our planet with raw materials, and have difficulty telling their own ilk from Cyborgs who occasionally come to rule humankind. Of course, science fiction stories cannot be regarded as serious forecasts because they often portray not the most probable but the most exciting future. But they are symptomatic the way they look to the future. It creates an affinity between science fiction and futurology, a vision that was a characteristic of humankind in the second half of the $20^{\text {th }}$ century. The attitude can be described as acceleration of the future as it treats as real and readily achievable the prospects most of which did not come true at the turn of the century and still look fairly fantastic. In other words, the forecasts were wrong because they were based on a substantial overestimation of the rate of scientific and technological development of mankind.

G. Wise threw some light on the accuracy of forecasting in the $1970 \mathrm{~s}$ by analyzing 1556 forecasts made in the period between 1890 and 1940 and divided them into four groups: a) those that came true, b) those that are in the process of coming true, c) those that have been neither confirmed nor refuted, and d) those that have not come true. He estimated that less than half of the forecasts have come true or are coming true while about a third have been definitively overturned (Dickson, 1977, p. 21).

The discrepancy between forecasts and reality can of course be attributed to the objective and subjective challenges of prognostication: the poor quality of forecasts, the stereotyped logic or "psycho-logic" fu- 
eled by man's penchant for wishful thinking and for extrapolating contemporary trends in a linear fashion (Benford, 1995), etc.

The assumption that "the same factors which worked in the past will shape the future" (Dickson, 1977, p. 74) is a shortcoming of most futurological methodologies. For "linear projections... have basic limitations, because they generally assume that present trends will continue whereas, in actuality, new techniques may be developed or alternative materials may be found that may alter current trends dramatically" (Leinwand, 1976, p. 23). Another obstacle to accurate forecasting is that the enthusiasts of new opportunities opened up by technology tend to ignore the limitations imposed by the social, economic and political factors, ${ }^{1}$ and as a result predict the spread of technically possible innovations sooner than they begin to spread in reality (Coates, 1998). The spin-offs of the introduction of new technologies are often ignored (Ibid.).

An important recurring psychological pattern in prognostication is that epoch-making technological breakthroughs such as man's landing on the moon dramatically increase human self-esteem creating a sense of omnipotence and a feeling that "everything will be different now," including here on the Earth (Dickson, 1977). However, things on Earth remain as they were.

The accuracy of forecasts has also been affected by the phenomenon described by Ch. Frankel as "telescoping of revolutions," that is, the fact that the main changes in the life of the human race occur over ever shorter time periods (Leinwand, 1976, p. 28) which leads people to think that future changes would happen even faster. J. Benford predicts that this trend will grow, stressing that the speed of the change of our own ideas about ourselves will increase and these ideas will change faster than we ourselves, which is already happening (Benford, 1995). ${ }^{2}$

All these factors, generated by the character of perception of the future have played a major role. As a result now that we are in the new mil-

\footnotetext{
1 And often the actual factors. For example, a scientist at the court of Louis XV came up with a projection that the monarch found very pleasant. However, before long it turned out that the generally accurate forecast failed to predict a trifling circumstance... The French Revolution (Dickson, 1977, p. 14).

2 It may not be irrelevant to note that perhaps the main mistake of the Soviet version of Marxism was that it presupposed the formation of "the new man" - not mercantile, selfless, putting society's interests above personal interests - whereas in reality human nature has hardly changed.
} 
lennium we find ourselves in a future very different from that we had expected. But there is another possibility which is that faced with different options of development humanity did not choose the option that seemed the most probable only a few decades ago. P. Dickson, as well as other futurologists emphasized that "a prediction that does not come true is not necessarily a bad prediction" (Dickson, 1977, p. 7). A. Toffler stressed that humankind always has a choice between variants of the future and the choice is determined not by scientific and technological factors, but by social and political circumstances (Toffler, 1976). As a result, the forecasts that have not come true reflect important trends and often outline variants of the future that appear to be more probable and more rational than the paths that humanity actually chooses. The gap between forecasts and reality expresses not so much the inaccuracy of forecasts as the "inadequacy of the choices" made by mankind and is itself a symbolic phenomenon that needs to be studied more closely.

\section{The "glut" of knowledge}

Looking at the causes of the divergence between forecasts and reality, it would make sense to look at the general trajectory of the development of modern science because it determines the main direction of technical progress and all the above-mentioned unrealized forecasts were based on overestimating its potential. In recent decades that trajectory revealed two noticeable twists, one of which was the diversion of the main cash flows away from fundamental science towards applied science, and the second was the reorientation of social interests among different areas of research.

Fundamental "cognitive" science has clearly been pushed into the background by applied science that "does things" and commercializes scientific knowledge. The funding of fundamental research is shrinking and the overall impressive amount of money spent on science comes mainly from such corporations as General Motors, General Electric, Panasonic, etc. which annually spend billions of dollars on research, but primarily applied research and development. In the Western countries most of the growth of national spending on science is accounted for by the industrial sector. For example in the US in the late 1990s it accounted for two out of every three dollars spent on scientific research and absorbed three quarters of all the national spending on science (Overview, 
1988). The change of the structure of the world market of hi-tech products between 1980 and 1995 is revealing (Table 1).

Table 1

Sectoral structure of hi-tech product market (\%)

\begin{tabular}{lcc} 
& $\mathbf{1 9 8 0}$ & $\mathbf{1 9 9 5}$ \\
\hline Computers and office technology & 14 & 30 \\
Electronics & 25 & 35 \\
Aerospace industry products & 18 & 9 \\
Pharmaceuticals & 6 & 4 \\
Arms & 3 & 1 \\
Other & 34 & 21 \\
\hline
\end{tabular}

Source: Second European Report on S\&T Indicators (1997).

The trend reflected in the table is fairly obvious: the share of computers and office technology has more than doubled, the share of electronics has increased substantially while the share of the aerospace industry has dropped by nearly a half. In other words, humanity has clearly preferred offices and computers to spaceships switching from the "space" to "computer" development trajectory, which could not but affect fundamental science.

A similar trend can be observed in the sphere of patents. Thus in 2005 the largest number of patents (16.8\%) was issued in the computer sphere. The top three areas also included telephony and data transmission systems $(6.73 \%)$, computer periphery $(6.22 \%)$ (OECD Science, Technology and Industry Scoreboard, 2005). We see the undisputed leadership of computer-related developments, and it is highly symbolic that one of the world's richest men, Bill Gates, made his impressive fortune in this field. Analysts at RAND Corporation believe that in the coming decades the rate of scientific and technical progress will not slow down, but it will occur in the same areas (RAND Corporation Report, 2006).

The above trend is manifested in most concrete sciences, including social sciences and the humanities. For example, M. Rosenzweig, analyzing the quantitative trends in psychological science, came to the conclusion that psychology is ceasing to be a scientific discipline and is becoming an area of practical activity (Rosenzweig, 1992, p. 37) as a result of which it may soon become "psychology without science" (Ibid., p. 37). 
Proceeding from his survey of psychology Rosenzweig suggests that one of the main obstacles to the development of psychological science is that it is cash-starved (Ibid.) whereas psychological practice has no reason to grumble about a shortage of funding.

One explanation for the change in the overall trajectory of the development of science is that fundamental science builds up its stock of knowledge faster than applied science can absorb and translate it into useful and profitable knowledge. As a result there is a "glut" of fundamental knowledge, the excess knowledge "undigested" by applied science is building up and society seeks to "put a brake" on fundamental science until the knowledge it has already produced is utilized. It is often said that the time of scientific discoveries has been replaced by the time of the use of the fruits of these discoveries and that fundamental science has been put on hold. Symbolically, the awards of Nobel Prizes in recent years demonstrate the foreshortening of scientific horizons. It has also been suggested that all the epoch-making discoveries have already been made and only "trifles" remain for science to deal with. The above explanation - the "glut" of scientific knowledge - can be reinforced by the observation that new scientific knowledge is a burden on humanity because it has to be absorbed, which has lengthened the educational cycles, has to be fitted into the existing pictures of the world and sometimes requires a rewriting of existing textbooks, etc. Conventional wisdom is that cognition is a value in itself while the idea of progress, directly connected with the development of science, "is deeply rooted in Western society and is supported by the Judeo-Christian ethic" (Leinwand, 1976, p. 48). However, the information load on humanity created by the development of science, irrespective of its ethical, ecological and other "abuses," appears to be too high a price for such progress. The works of such remarkable authors as A. Toffler demonstrate the severe psychological consequences of too rapid development of civilization that breeds "stop the world - I want to get off"3 sentiments (Toffler, 1970).

The idea that existing knowledge is "sufficient" and that the development of fundamental science should be "suspended" would surely provoke an outcry not only among scientists but among the whole progressive humankind. Their arguments could be that "extending the frontiers of knowledge" is an intrinsic value, the presumption that humanity has an

3 Title of a stage play popular in the US in the 1970 s. 
inherent need to extend them and the obvious circumstance that many of the key problems facing it have yet to be solved, and the solution is impossible without producing new fundamental knowledge and cannot be achieved by merely using the existing knowledge. At the same time the need to extend these "frontiers" in all directions has been put into question. Doubts are frequently voiced about the practicability of space exploration: of course we are interested to know what is happening in other worlds, but satisfying this curiosity costs too much, there are no significant returns on such exploration in sight, so would it not be better to concentrate on more pressing terrestrial problems? Such a line of reasoning would have looked absurd in the times of Columbus, but in this connection one should mention if not the destruction, certainly a weakening of the traditional Protestant values which have always been loyal servants of science (Merton, 1973). It is noted that "industrialized Western society has, since the $17^{\text {th }}$ century, been dominated by the Puritan work ethic that values hard work, encourages frugality, favours savings, postpones pleasure, defers gratification and countenances austerity" (Leinwand, 1976, p. 43). Present-day Western society is living through a crisis of these values, it is characterized by the "here-and-now" mentality with narrowly pragmatic orientation, quick gratification, etc. As a result the modern man hates to wait and, accordingly, hates to see his money being spent on what may bring fruit only in the remote future, if at all. The majority of modern humanity, including its "golden billion," obviously does not share the formula of the founder of the Siemens concern: I will not betray the future for the sake of quick money (Pierer, 1999, p. 16). As a result "the extensions of the frontiers of knowledge" and the prospect of flights to other planets and contacts with extraterrestrial civilizations which thrilled the preceding generations, are no longer as thrilling and the current generation is skeptical about "discoveries made ahead of their time," which, like the theory of relativity, yield no commercial results, unless of course one counts in the huge number of sci-fi novels and films where time and space keep transmuting into each other.

\section{Introversion of civilization}

In connection with the forecasts which have not come true one should mention the trend of "virtualization of the modern civilization" which has been engendered by science but, like many other scientific 
products, is undermining its own positions. The virtual world performs the function of replacing reality, creates an environment in which a person can meet the needs that cannot be met in real life. It performs that function not only with regard to an individual who has specific psychological needs, for example change of gender, which can much more easily be effected through the Internet than in real life, but also with regard to humanity as a whole. The modern man would like to know how other worlds and aliens from outer space look. But why wait for science to make it possible if he already has it at his disposal in the shape of films about star wars and extraterrestrials?

Science has traditionally performed the "miracle-making" function, which was very important for mass consciousness, it has acquitted itself as "the conveyor that produces miracles" generating interesting and exciting images of the world which are now created with equal success by the cinema, itself a product of science. The development of film-making technology, making films still more like reality can contribute to the fulfillment of that function at least as much as real penetration of science into the worlds it models.

This state of mass psychology has a direct impact on science, for whatever national priorities may be declared by governments, in democratic societies the main development trajectory is determined... by the man in the street in his capacity as voter and tax payer. The man in the street hates to see his money being spent on what promises something, like spaceflights and "extension of the frontiers of knowledge" that is far removed in time and from his personal needs. The author of the book Biopsychology, J. Pinel, subjects his readers to a kind of test by asking them whether they would be ready to shell out hundreds of thousands of dollars to finance the studies of motor neurons, the learning of the newly-hatched ducks, the activity of the nervous cells of the eyesight system of monkeys, hypothalamic hormones of pigs and sheep or corpus callosum, the big neuron pathway that links the left and right cerebral hemispheres (Pinel, 1993, p. 11). Foreseeing the result, he adds that the lay reader would be surprised to learn that each of these studies has been crowned with... a Nobel Prize (Ibid.).

In modern society science develops in the direction of the main cash flows, which in turn are directed by the dominant social interests expressing the mentality of the modern man. A mere "glut" of fundamental knowledge would not be enough to change the overall trajectory of the 
development of science or bring about a "suspension" of fundamental science. It took for a substantial change of the value priorities of modern humanity. The change is expressed in the formula "the market puts everything in its place" and "market decisions" are symptomatic of the modern civilization creating phenomena which, though habitual, look paradoxical in terms of common sense and the general logic of the development of the human race. Let us imagine a fantastic situation: representatives of an extraterrestrial civilization come to our planet. Like us, they have mastered the market economy, but it is oriented primarily to scientific-technological and social progress, just like human science has been most of the time. The chances are they would assume that representatives of various professions are paid in proportion to their contribution to this progress. And what would they have found on the Earth? That a pop star or a sports star earns ten times more than a Nobel Prize winner, i.e. they would see an inversion of the "rational market formula." Surely it would strike them as totally absurd, as a proof of the barbaric state of our civilization and they would probably draw conclusions about humanity that would make them less eager to have contacts with us. ${ }^{4}$

A modern lay person perceives such paradoxes as normal, i.e. does not see them as paradoxes, while the intelligentsia, though regarding them as anomalies, attributes them to "abuses" of the market similar to the "abuses" and obvious absurdities of democracy. This view of things, if not actually mistaken, is at least a little off-focus and the corresponding anomalies are not "abuses" or artifacts, but telltale anomalies which embody very important characteristics of the modern civilization. The profession of our time is not a scientist, but a showman, which expresses a very characteristic civilization fault line.

Perhaps the conclusion that the humanity has swapped the "paradigm of development" for the "paradigm of leisure" 5 would appear too categorical to some. However, the concentration of the main financial resources in the leisure sphere - show business, etc., the fact that ath-

4 This plot line has been repeatedly used in sci-fi novels and films: highly developed aliens come to us, but finding nothing worthwhile on Earth fly away in order to return later when humanity "will become wiser and mends its ways".

5 That has been predicted. See, for example, the prediction that "social inventions in the future will require us to assume a new attitude toward leisure and to attempt to make leisure as meaningful and as central as work once was" (The Future is Now, p. 64). 
letes and singers are much more famous than scientists - do appear to be symbolic phenomena. Combined with the prevalence of day-to-day problems over the problems that stirred the imagination of humanity throughout its history, all this warrants the conclusion about the "introverted civilization," its transition from "outward-looking development" (directed initially at exploring new territories and then the outer space and new levels of matter) to "inward-looking development," whose leitmotif is more comfortable life rather than universal orientation. This may account for the main mistake of the futurological and sci-fi forecasts in the second half of the $20^{\text {th }}$ century which were based on the presumption that human nature is immutable and accordingly, that the expansionist "outward-looking" - development of humankind will continue.

The reorientation of much of the humanity to the "paradigm of leisure" reminds one of the theory of A. Maslow who distinguished five levels of human needs: 1) physiological needs: food, drink, etc., 2) the need for security, 3) the need for a sense of belonging and affection, 4) the need for self-respect, 5) the need for self-realization (Maslow, 1954). According to Maslow, the needs of ever higher levels are met successively as lower-level needs are gratified. If one applies the same logic to humanity as a whole, or at least its Western part, one would expect that once society satisfied its basic material needs it would switch to meeting the needs outside the material sphere. In Maslow's theory, these are the needs for fulfilling one's creative potential, etc., which, incidentally, is very similar to the Communist myths about the future of mankind when man after meeting his material needs, will not proceed to "hyper-gratification," for example, by acquiring a second, third or tenth car (it will be recalled that according to this myth everything will be in abundance and for free in the Communist future) but will take to writing books or painting.

However, staying within Maslow's logic, it is possible to enlarge his list of basic needs and their content. The need for self-respect, for example, can be met by buying a mansion, a yacht, a dozen cars, while selffulfillment can be achieved by gambling in a casino or visiting trendy social gatherings. That is entirely within Maslow's $\operatorname{logic}^{6}$ and, moreover, it provides a psychological explanation of what is happening to the modern civilization.

6 It only challenges its underlying presumption regarding human nature which he clearly oversimplifies. 
What is happening was predicted by futurologists who in the mid1970s asked the questions like this: "would a leisure ethic replace a work ethic if mankind no longer had to work hard and be completely productive to survive?" (Leinwand, 1976, p. 44). The economist J. Keynes predicted that "if the economic problem is solved, mankind will be deprived of its traditional purpose" (Keynes, 1963, p. 366). And still earlier E. Durkheim stressed that the development of industry and infinite expansion of markets would inevitably spur on boundless growth of human desires and passions (Durkheim, 1952). Psychologists have long noted the decline of the traditional Western Protestant ethic that puts a premium on patience, suspension of immediate gratification, thrift, putting aside money "for a rainy day," and its displacement by the "hearand-now mentality" whose characteristics are diametrically opposite: the habit to live on debt, massive wish to possess today what you will earn tomorrow, the tendency not to think about tomorrow, to live today as if it were one's last day. This consumer mentality is complemented by the similar mentality of entrepreneurs who seek to sell today what the consumer can pay for only tomorrow. That created an addiction to credit as a disease of Western society which until recently was seen as an indisputable boon to the economy. Not content with the credit obligations have entrepreneurs sought to convert into cash by selling these obligations, issuing derivatives, which led to the creation of a "pyramid" and had to collapse some day (there are at least 30 virtual dollars for each real dollar in the world economy, dollars existing in the shape of various obligations). These new notorious economic processes which have resulted in a world economic crisis were based on a psychological phenomenon, the universal wish to have today what you will earn (deserve) only tomorrow, as the Protestant ethic is supplanted by the mentality of the "here and now."

Many futurologists were aware that scientific and technical progress inevitably creates new values and could dramatically change not only the scientific and technical look but also the values of humanity. The alternative was formulated in the following way: "does technology alter the values by which we live, or do our values determine the technology that will be developed?" (Leinwand, 1976, p. 30). The two determining vectors of what is happening in society have been reconciled in the most natural way: the development of technology is based on the system of values which in turn stimulates the development of science and technol- 
ogy (Ibid.). It has been noted that the change of values could be as important a result of technological development of mankind as the technical results themselves and predictions have been made to the effect that "just as social invention may be far more far-reaching than technological invention, the values we come to hold may be more important than the things we invent" (Ibid., p. 30). ${ }^{7}$

However, the prevalence of the technology-oriented logic, so pronounced in the forecasts of the 1970s that have not come true, is still characteristic of Western futurology, as witnessed by the forecasts made in the 1990s. Below are some of them.

- Thanks to the spread of genetic cosmetics people will be able to choose the colour of their eyes and hair, their skin, height etc. (Benford, 1995).

- Genetic design of animals will become widespread: talking dogs, green cats to match the interior decorations of the home, etc. (Ibid.).

- Special bio-mats would absorb pools of soapy water, the soap spots and other "waste" (Ibid.).

- Clothes will be replaced with bio-velvet, bio-cloth, bio-silk, etc, which will live off our skin and feed on its secretions (Ibid.).

- "Brain technologies" will go far beyond the creation of drugs and would make it possible to "tweak" the human psyche and develop man's capabilities (Coates, 1998).

- Schizophrenia and depressions will become history (Ibid.).

- By 2005 the sequence of genes in the DNA molecules of a typical male and a typical female will be known and by 2025 the technique of cloning concrete human organs will be mastered (Miller, Michalsky \& Stivens, 1998).

- Robots will walk in the streets, perform the functions of baby-sitters, servants and do all the chores that people do today (Ibid.).

- Completely "robotized" production which does not require human participation will become possible (Coates, 1998).

7 It has already happened to such "social inventions" as Socialism. In general, most Western futurological projections single out four groups of factors that are critical for the development of mankind: energy, climate, food and social values (Ibid., p. 127). The latter are seen as being as important in determining human development as the first three "material" factors. 
- "Planetary engineering," i.e. the dumping of human waste into the Earth's mantle, will become widespread (Ibid.).

- It will be possible to transport icebergs to irrigate arid areas (Ibid.).

- Ranches and farms will be created in the oceans and minerals will be extracted from the ocean floor (Ibid.).

- People will be able to create and alter natural terrains (Ibid.).

It is not hard to see that these forecasts are informed with the same logic that inspired the unrealized forecasts of the 1970s: man, like humanity as a whole, practically does not change and "remains himself," except that there will be no depressions or schizophrenia, no people with unpopular colour of the eyes and hair and the development of civilization will be directed entirely by the broadening of its technological opportunities. As the fate of futurological and sci-fi forecasts demonstrates herein lies a big mistake. While that mistake is being made we will have to resign to creating a very different kind of future than that we predict and long for.

\section{References}

Asimov, A. (1976). Tighten your Belt. In G. Leinwand (Ed.), The Future (pp. 220228). New York: Pocket Books.

Benford, G. (1995). Biology: 2001. Reason Magazine, November.

Coates, J. (1998). The Next Twenty-Five Years of Technology: Opportunities and Risks. In $21^{\text {st }}$ century technologies: promises and perils of a dynamic future (pp. 33-46). P.: OECD.

Dickson, P. (1977). The Future File: A Guide for People with One Foot in the $21^{\text {st }}$ Century. New York: Rawson Associates Publishers, Inc.

Durkheim, E. (1952). Suicide: A Study in Sociology. London: Routledge and Kegaen Paul.

Keynes, J.M. (1963). Essays in Persuasion. New York: Norton.

Leinwand, G. The Future is Now. In G. Leinwand (Ed.), The Future (pp. 13-65). New York: Pocket Books.

Maslow, A.H. (1954). Motivation and Personality. New York: Harper \& Brothers.

Merton, R. (1973). The Sociology of Science: Theoretical and Empirical Investigation. Chicago: University of Chicago Press.

Miller, R., Michalsky, W., \& Stivens, B. (1998). The Promises and Perils of $21^{\text {st }}$ Century Technology: On Overview of the Issues. In $21^{\text {st }}$ Century Technologies: Promises and Perils of a Dynamic Future (pp. 7-32). P.: OECD. 
OECD Science, Technology and Industry Scoreboard 2005. (2005) P.: OECD.

Overview: Science and Technology in Transition to the $21^{\text {st }}$ Century (1998). In National Science Board Science and Engineering Indicators: 1998. Wash. DC: U.S. Gov. Print. Off.

Pierer, H. (1999). Managing a Global Player in the Age of Infernation. Managing International Review, 39 (3), 9-17.

Pinel, J.P.J. (1993). Biopsychology. Boston: Allyn and Bacon.

Polak, F.L. (1973). The Image of Future. Amsterdam: Elsevier Scientific Publishing.

Ritchie-Calder, L. (1976). The Next Billion Years Start Now. In G. Leinwand (Ed.), The Future (pp. 206-214). New York: Pocket Books.

Rand Corporation Report "The Global Technology Revolution 2020: In-Depth Analysis." (2006). CA: Rand.

Rosenzweig, M.R. (1992). What Is Psychological Science. In M.R. Rosenzweig (Ed.), International Psychological Science: Progress, Problems, and Prospects. Wash.: American Psychological Association.

Second European Report on S\&T Indicators (1997). Brussels: European Commission.

Toffler, A. (1970). Future Shock. New York: Random House.

Toffler, A. (1976). The Predesigned Body. In G. Leinwand (Ed.), The Future (pp. 152-168). New York: Pocket Books.

Torrance, E.P. (1978). Giftedness in Solving Future Problems. Journal of Creative Behaviour, 12 (2), 75-86.

Wheeler, H. (1976). Beyond Tomorrow - What? In G. Leinwand (Ed.), The Future (pp. 187-205). New York: Pocket Books. 